\title{
PERBANDINGAN KONSEP TATA KELOLA PEMERINTAH: SOUND GOVERNANCE, DYNAMIC GOVERNANCE, DAN OPEN GOVERNMENT
}

\author{
(Comparative Concept of Governance: Sound Governance, Dynamic Governance, \\ And Open Government)
}

\author{
Lesmana Rian Andhika \\ Ilmu Administrasi Fakultas IImu Sosial dan IImu Politik \\ Universitas Padjadjaran \\ Jl. Bukit Dago Utara No. 25 Bandung 40135 \\ e-mail: lesmana15001@mail.unpad.ac.id
}

Naskah diterima: 25 September 2017

Naskah direvisi: 01 Oktober 2017

Naskah diterbitkan: 31 Desember 2017

\begin{abstract}
The concepts of good governance, sound governance, dynamic governance, and open government are often used as references in order to likely manage the government activities properly. Any concept of governance adopted implies to reject any form of authoritarianism, corruption, collusion, and nepotism that will open up opportunities for malicious actions in carrying out government activities. The research aims to explore theoretical conceptual framework and to compare among the concepts of relevant scientific literature. Many studies argue that the concept of governance adopted is not necessarily and successfully implemented in different offices. This article is a synthesis of qualitative research which uses meta-theory method (the analysis of theory). This research seeks to identify some of the existing written evidence on the subject of research. The results reveal that governance model is adopted because of the need to respond to various issues of government activity. Various models of governance arise to fill the shortcomings of preexisting concepts with different approaches and focuses. Other results also reveal that the concept of governance has its essence and refer to government innovation as an effort to manage government activities, and to deliver good public services. Nevertheless, the concept of governance will be meaningless if it is run by people with low-quality, unintelligent, and unresponsive.

Keywords: comparative, governance, innovation, government
\end{abstract}

\begin{abstract}
Abstrak
Konsep tata kelola pemerintahan dari good governance, sound governance, dynamic governance, dan open government merupakan sebuah konsep rujukan yang dianggap dapat mengelola aktivitas pemerintahan dengan baik. Konsep tata kelola pemerintah apa pun yang diadopsi menyiratkan untuk menolak berbagai bentuk aktivitas pemerintah yang didasari dari kegiatan otoritarian, korupsi, kolusi, dan nepotisme yang akan membuka peluang tindakan-tindakan jahat lainnya dalam melaksanakan aktivitas pemerintah. Tujuan penelitian ini berusaha memberikan kontribusi pengetahuan dengan mengeksplorasi konseptual teoritis dan membandingkan di antara konsep tersebut dari literatur ilmiah yang relevan, berbagai argumentasi mengungkapkan belum tentu konsep tata kelola pemerintah yang diadopsi bisa dan sukses dilaksanakan pada tempat yang berlainan. Artikel penelitian ini merupakan synthesis of qualitative research, dengan menggunakan metode meta-theory (the analysis of theory). Penelitian ini berusaha untuk mengidentifikasi beberapa bukti tertulis yang ada mengenai tema penelitian. Hasil penelitian mengungkapkan, tata kelola pemerintah diadopsi karena kebutuhan untuk merespon berbagai masalah aktivitas pemerintah. Berbagai model tata kelola pemerintah itu muncul akibat adanya pemikiran baru untuk mengisi kekurangan dari konsep yang telah ada sebelumnya dengan pendekatan dan fokus yang berbeda. Hasil lain juga mengungkapkan bahwa konsep tata kelola pemerintah memiliki intisari dan merujuk kepada inovasi pemerintah sebagai upaya untuk mengelola aktivitas pemerintah, dan berkontribusi menghadirkan pelayanan publik yang baik. Konsep tata kelola pemerintah akan tidak bermakna apabila dijalankan oleh orang-orang dengan kualitas sumber daya manusia rendah, tidak cerdas, dan tidak responsif.

Kata kunci: perbandingan, tata kelola, inovasi, pemerintahan
\end{abstract}

\section{PENDAHULUAN}

Teori dependensi (dependency theory) mengajarkan kita bahwa ketergantungan negaranegara miskin (lebih banyak merujuk kepada negara berkembang) kepada negara kaya (maju) yang berawal dari kasus negara-negara Amerika Latin. Tujuannya mengintegrasikan negara berkembang ke dalam sistem dunia dengan seperangkat aturan yang harus dipatuhi. Teori dependensi merupakan anti tesis dari teori modernisasi yang menyatakan semua kemajuan dan perkembangan sebuah negara adalah hak yang sama di antara negara maju dan berkembang. Biasanya selalu terkait dengan sistem ekonomi (pendapatan sebuah negara, perdagangan) dengan cara investasi, transfer teknologi terkini. Namun dependensi menolak anggapan modernisasi dengan alasan negara maju sering mengklaim negara berkembang adalah negara primitif. Dalam situasi ketergantungan itu, ekonomi negara-negara berkembang selalu diintervensi oleh negara maju (ekspansi) modusnya adalah ekplorasi sumber daya alam dan menempatkan negara berkembang dalam 
posisi yang lemah dalam sistem dunia (lihat lebih lanjut Caporaso, 1978; Namkoong, 1999).

Berawal dari ketergantungan tersebut berbagai krisis menimpa negara berkembang seperti krisis ekonomi, kemiskinan, dan kelaparan. Oleh sebab itu negara maju merasa berkewajiban membantu negara-negara yang terkena krisis tersebut dengan perantara lembaga-lembaga donor dunia (UNDP, IMF, World Bank, ADB, UE). Salah satu penyebab timbulnya krisis tersebut adalah penyelenggaraan pemerintah yang tidak baik, tingginya korupsi, kolusi, nepotisme, penyalahgunaan anggaran yang mengakibatkan kemiskinan suatu negara. Solusi pencegah yang ditawarkan oleh lembaga-lembaga donor melalui konsep good governance. Konsep penyelenggaraan pemerintah yang baik menjadi pintu masuk bagi mereka dengan sejumlah aturan yang harus dipatuhi bila ingin mendapatkan bantuan dari lembaga donor dan ikut berpartisipasi dalam menyelesaikan krisis di sebuah negara. Contoh Indonesia dengan krisis moneter yang melanda di tahun 1997. Lembaga donor International Monetary Fund (IMF) menawarkan bantuan kemudian para elit negara menyetujui sejumlah aturan dengan alasan untuk menyelamatkan negara dari kebangkrutan (failed state). Alasan tersebut dapat kita terima, namun dibalik aturan yang ditawarkan lembaga donor ada dampak yang harus ditanggung oleh negara. Sebagai contoh, menghambat pengembangan pesawat jet penumpang N2310 kapasitas 80-130 penumpang yang telah ditetapkan sebagai proyek nasional oleh Presiden Soeharto tahun 1995. Pesawat jet penumpang ini merupakan pesawat canggih di kelasnya dengan menggunakan advance fly by wire, pada saat itu Airbus dan Boeing belum mengadopsi dan menggunakan teknologi ini. Salah satu kebijakan IMF adalah menghentikan program tersebut, secara eksplisit kebijakan itu merupakan strategi kapitalisasi modern untuk menghentikan pesaing, karena Airbus dan Boeing merupakan beberapa donatur utama dari IMF.

Pemikiran klasik tentang teori pemerintahan berkutat pada penyelenggaraan pemerintahan yang sentralistik yang mengakibatkan kegagalan dalam efisiensi pemerintahan yang selalu dicampuradukkan dengan politik. Dengan perkembangannya maka dituntut untuk menghadirkan pelayanan publik yang baik dari negara terhadap warganya. Adopsi prinsip swasta sangatlah rasional, prinsip manajemen, prinsip mekanisme pasar, pengalokasian, dan pengembangan sumber daya manusia mengilhami munculnya konsep tata kelola pemerintahan yang baik (good governance). Walaupun kritikan mengatakan konsep good governance merupakan konsep imperialisme dan kolonialisme dari negara maju (Farazmand, 2004). Tidak bisa dibantah lagi bahwa kehadiran konsep good governance cukup revolusioner untuk menghadirkan tata kelola pemerintahan yang baik bagi negara-negara berkembang (Holzhacker, Wittek, \& Woltjer, 2016).

Kritikan terhadap konsep good governance yang dianggap sebagai model imperialisme dan kolonialisme baru, maka muncul pemikiran untuk menghubungkan kemandirian sebuah negara (berkembang) dengan praktek-praktek sistem dunia secara universal. Sound governance, dymanic governance, dan open government adalah konsep evolusi dari good governance. Konsep-konsep ini hanya bertujuan untuk mencari cara dan model baru menata dan mengelola pemerintahan dengan baik untuk menyelesaikan masalah pemerintah.

Sebagai contoh kasus korupsi, laporan dari Transparency International tentang corruption perception index (CPI) 2016 menempatkan Indonesia rangking 90 dengan skor 37 masih di bawah negara ASEAN lainnya seperti Singapura, Brunei, dan Malaysia (Transparency International, 2017). Dalam hal pengelolaan prinsip-prinsip governance, Worldwide Governance Indicators memberikan penilaian kepada Indonesia dengan beberapa kriteria governance yaitu voice and accountability $(52,22)$, political stability and absence of violence/terrorism $(24,76)$, government effectiveness $(46,15)$, regulatory quality $(47,12)$, rule of law $(39,90)$, control of corruption $(38,46)$ (World Bank, 2017). Data lain dapat ditelusuri juga dari laporan Ombudsman Republik Indonesia tahun 2015 melaporkan, secara nasional ada 6.859 (enam ribu delapan ratus lima puluh sembilan) laporan/ pengaduan masyarakat tahun 2015, sebanyak 41,59 persen atau 2.853 (dua ribu delapan ratus lima puluh tiga) laporan, mengeluhkan pelayanan publik di instansi pemerintah daerah (Ombudsman Republik Indonesia, 2016). Laporan lain juga dapat ditelusuri dari berbagai laporan akuntabilitas kinerja instansi pemerintah (LAKIP) namun setiap instansi menunjukkan laporan yang berbeda sesuai dengan wewenang dan fungsinya. Laporan hasil evaluasi pelaksanaan reformasi birokrasi, akuntabilitas, dan zona integritas pada instansi pemerintah tingkat kabupaten/kota menunjukkan pada nilai hasil evaluasi lebih banyak pada kategori CC (168), C (231), D (67) dari 416 Kabupaten, 98 Kota se-Indonesia (Kemenpan RB, 2015).

Data di atas menggambarkan masih belum maksimalnya pengelolaan tata kelola pemerintah yang baik terutama pada pemerintahan daerah. Diperlukan terobosan yang koheren antara beberapa konseptualisasi dan prakteknya untuk menciptakan tata kelola pemerintahan yang baik. Beberapa temuan literatur tentang studi tata kelola pemerintah 
sudah pernah dilakukan. Seperti, studi tentang good governance, Okechukwu (2012) dalam studinya menemukan gaya kepemimpinan yang etis akan menghasilkan implikasi terhadap perubahan sosial yang positif terletak pada penyampaian informasi kepada publik dengan potensi untuk memanfaatkan sumber daya untuk mengembangkan situasi sosial ekonomi, dan meningkatkan kualitas tata kelola pemerintahan (kasus negara Nigeria). Studi sound governance diantaranya, Holidin \& Handini (2014) menunjukkan, ada pendekatan baru dalam menjalankan program inovatif tradisional revitalisasi pasar dan pengelolaan pedagang kaki lima (PKL) melalui pengembangan lingkungan yang adaptif tanpa membuang orientasi menuju pemberdayaan masyarakat. Dianalisis secara univariat dan deskriptif terhadap dimensi-dimensi sound governance (kasus kota Surakarta). Firdaus (2016) mengeksplorasi dan menganalisis praktik tata kelola sound governance dalam program pengembangan kawasan Metropolitan Mamminasata yang berfokus pada lima dimensi, yaitu proses, struktur, nilai, manajemen, dan kebijakan yang bertumpu pada pelaksanaan koordinasi, integrasi, sinkronisasi untuk mewujudkan interkoneksi pembangunan lintas kabupaten/kota (kasus provinsi Sulawesi Selatan). Studi tentang dynamic governance juga pernah dilakukan, Gulbrandsen (2014) menunjukkan, konsep dynamic governance akan lebih bermanfaat apabila kebijakan pemerintah turut berinovasi. Rajan (2017) mengungkapkan, tata kelola organisasi yang dinamis lebih kepada perubahan sistem intitusional lembaga pemerintah dengan gerakan reformasi birokrasi, perubahan kebijakan pemerintah, dan devolusi (desentralisasi) strategis (kasus negara India).

Penelitian tentang konsep tata kelola pemerintah yang lain seperti open government juga pernah dilakukan. Yang, Lo, \& Shiang (2015) menemukan secara khusus faktor-faktor yang berpengaruh dan dampaknya terhadap inisiatif open government diselidiki dari empat perspektif yaitu legislasi dan kebijakan, teknologi, organisasi, dan lingkungan. Legislasi dan kebijakan ditemukan memiliki dampak paling signifikan, sementara lembaga peraturan dan kebijakan yang ada bertindak sebagai kendala. Faktor teknologi memberikan kendala namun dianggap relatif lebih mudah terselesaikan dengan dukungan yang memadai. Faktor-faktor yang berada dalam perspektif organisasi dan lingkungan mengikuti dampak secara sekunder (kasus negara Taiwan). Blasio \& Selva (2016) mengemukakan, kebijakan open government (transparansi, partisipasi, kolaborasi, dan juga digital teknologi) menyebar di seluruh Eropa sebagai model pemerintahan yang baru, namun tidak homogen di berbagai negara yang menunjukkan adanya persaingan. Di satu sisi, hegemoni model open government nampaknya menekankan inovasi dan keterbukaan dalam arti transparansi yang disempurnakan, terkadang dilakukan oleh kolaborasi antara publik dan swasta. Namun gagal mencapai keterbukaan dalam pengambilan keputusan meski telah dipaksa oleh dorongan menuju inovasi dalam proses pembuatan kebijakan sudah terkonsolidasi secara mekanisme, bukan perubahan substantif (studi komparatif antara negara Prancis, Italia, Spanyol, dan Inggris).

Intisari dari beberapa studi di atas menggambarkan untuk mencapai tata kelola pemerintah yang baik ada beberapa hal yang perlu diperhatikan, 1) Faktor pemimpin menjadi bagian penggerak perubahan; 2) Organisasi pemerintah menjadi katalisator perubahan; 3) Kebijakan pemerintah yang menghambat perubahan direvisi kembali agar lebih memihak kepada perubahan. Konsekuensi dari beberapa argumentasi di atas akan menimbulkan pemahaman, konsep apapun yang ditawarkan secara parsial atau simultan akan menuju sebuah perubahan dalam tata kelola pemerintah agar menjadi lebih baik.

Fokus tujuan penelitian ini berusaha memberikan kontribusi pengetahuan dengan mengeksplorasi konseptual teoritis dari berbagai literatur ilmiah yang relevan karena belum tentu konsep tata kelola pemerintah yang diadopsi bisa dan sukses dilaksanakan pada tempat yang berlainan. Sehingga perdebatan logis tentang perbandingan konsep tata kelola pemerintah tidak hanya dilihat dari sisi positif konsep namun juga dilihat dari sisi negatif untuk menyikapi permasalahan penelitian yang terdeskripsi dalam beberapa pertanyaan penelitian, 1) Bagaimana perbandingan dari tata kelola pemerintahan itu sendiri; dan 2) Bagaimana sisi positif dan negatif konsep tersebut.

\section{METODE}

Metode dalam artikel penelitian ini adalah synthesis of qualitative research. Metode yang diartikan sama dengan kata synthesis of qualitative research seperti meta-narrative synthesis, critical interpretive synthesis, meta-study, metaethnography, grounded formal theory, thematic synthesis, textual narrative synthesis, framework synthesis, and ecological triangulation (Barnett \& Thomas, 2009). Barnett \& Thomas (2009:7) kembali menjelaskan, meta-study mempunyai tiga komponen analisis yakni meta-data-analysis (the analysis of findings), meta-method (the analysis of methods), and meta-theory (the analysis of theory). Lebih spesifik artikel penelitian ini mengunakan meta- 
theory (the analysis of theory). Zhao (1991:378) menulis, metatheorizing as a means of attaining a deeper understanding of theory. Penelitian ini berusaha untuk mengidentifikasi beberapa bukti tertulis yang ada mengenai tema penelitian untuk membangun pengetahuan penelitian pendahuluan. Harapannya dengan kajian secara sistematis dapat memahami perbandingan tata kelola pemerintahan yang baik.

Penggalian data pada penelitian ini dilakukan secara deduktif atau theoretical and analytical frameworks, yang berasal dari berbagai literatur ilmiah baik bersumber dari buku maupun jurnal. Meta-theory bisa digunakan untuk mengidentifikasi kerangka teori yang berhubungan dengan teoriteori sosial, sejarah, budaya dan politik (Paterson, et.al, 2001). Untuk dapat menjawab pertanyaan penelitian, maka langkah-langkah meta-theory dalam artikel penelitian ini mengikuti petunjuk yang diberikan oleh Zhao (1991) yaitu, 1) restudying the same phenomenon that was previously studied (replication, for example) and 2) studying the results and the processes of the previous studies.

\section{HASIL DAN PEMBAHASAN}

Dekade terakhir konsep good governance dianggap merupakan sebuah konsep yang benar dalam negara demokrasi (terutama dalam kajian administrasi publik) untuk menata dan mengelola pemerintahan dengan baik. Para mahasiswa selalu disuguhkan dengan pemahaman epistimologis konsep good governance yang diadopsi oleh beberapa negara maju sebagai rujukan bagi negara berkembang. Kemudian secara aksiologis digunakan oleh negara berkembang secara universal. Walaupun latar belakang konsep good governance secara eksplisit akan menarik negara berkembang di dalam pusaran ketergantungan dan intervensi, dan dengan mudah mereka akan diatur oleh seperangkat kebijakan yang mengikat dibuat oleh lembaga donor. Gerakan globalisasi yang terus berkembang secara dinamis membawa perubahan terhadap degradasi lingkungan, kapitalisasi ekonomi, dan kemiskinan (Farazmand, 2004). Namun, penyesuaian globalisasi itu diikuti dengan transformasi pemerintahan dan administrasi (Kakabadse, et.al, 2011). Proses administrasi pemerintahan, struktur, nilai-nilai pemerintahan, kebutuhan untuk pengembangan kapasitas, inovasi dalam kebijakan, dan manajemen menjadi lebih efektif dari pada sebelumnya. Keefektifan pemerintah itu didasari dari berbagai pilihan kebijakan yang ada. Pilihan kebijakan pemerintah berbeda dengan praktiknya, ini akan memberikan penjelasan logis diantara kebijakan pemerintah yang berhasil atau tidak (Neo \& Chen, 2007).

Memulai diskusi dalam penelitian ini peneliti ingin menunjukkan definisi dari beberapa konsep tata kelola pemerintahan sehingga pemetaan masalah penelitian ini tidak menjadi kabur. Dalam artikel ini tidak lagi membahas tentang definisi, dimensi, efek positif dan negatif dari good governance karena konsep ini telah begitu populer dikalangan akademisi, praktisi, dan aktor kebijakan pemerintah. Di Indonesia konsep sound governance, dynamic governance, dan open government sepertinya belum begitu populer. Dari beberapa temuan literatur ilmiah yang ada selalu mengkaji penerapan ketiga konsep ini pada pemerintah sebagai landasan untuk melakukan perubahan tanpa membedah bagaimana perbandingan tata kelola pemerintahan, kekuatan, kelemahan, serta efek positif dan negatif konsep tersebut. Penelitian ini akan mengisi celah kekosongan tersebut.

Sound governance, Farazmand (2004:10-11) menjelaskan,

The concept of "sound governance" is used in this book as an alternative to the term good governance... hence, the concept of "soundness" is used to characterize governance with superior qualities in functions, structures, processes, values, dimensions, and elements that are necessary in governing and administration.

Tata kelola yang baik terdiri dari beberapa komponen utama. Sebagai sistem yang dinamis, unsur-unsur komponen utama itu seperti proses, struktur, nilai pengetahuan, aturan, organisasi, manajemen, kebijakan, sektor swasta, globalisasi, akuntabilitas, dan transparansi (Farazmand, 2004). Berinteraksi secara dinamis satu sama lain dan semuanya membentuk kesatuan yang unik dengan membangun inklusifitas relasi politik antara negara/ pemerintah, civil society, dan sektor bisnis. Beroperasi dengan keragaman, kompleksitas, intensitas internal, tantangan eksternal, hambatan, dan peluang untuk menjaga agar sistem pemerintahan tetap fokus pada arahan dan tindakan dengan tujuan. Sedangkan karakteristik dari proses tersebut berkontribusi pada peningkatan kapasitas, inovasi, kreativitas, dan respon adaptif. Farazmand (2004:19) menegaskan, innovation is key to sound governance, and innovation in policy, and administration is central to sound governance as well. Secara konseptual teoritik, inovasi bercerita tentang semua komunikasi yang menggabungkan perilaku biologis dan teknis manusia (lihat lebih lanjut Herbig \& Dunphy, 1998).

Oleh sebab itu, praktek administrasi publik tradisional pada kegiatan pemerintah menjadi 
semakin sulit terlaksana karena perbaikan konsep dilakukan secara ilmiah dan pemanfaatan teknologi. Serta didorong oleh globalisasi ekonomi yang telah menyulitkan pembangunan sosial ekonomi-politik, isu-isu yang muncul membawa kepada sebuah gagasan transformasi dan tantangan yang sangat besar bagi pemerintahan. Sebaliknya, isu tata kelola pemerintah daerah dan nasional yang mengarah kepada model kapitalisme dipengaruhi oleh norma, standar yang pasti (biasanya berbentuk angkaangka), dan rezim internasional (lembaga donor) yang mengatur tata kelola dalam negeri di berbagai bidang ekonomi, politik, masyarakat, budaya, dan administrasi pada akhirnya menimbulkan intimidasi sumber daya alam menjadi fenomena yang patut untuk dicermati. Banyak masalah tata kelola pemerintah terutama negara berkembang menjadi isu yang berkaitan secara global yang menuntut informasi dan teknologi bersama. Sebagai contoh, korupsi di sebuah negara akan memaksa kerja sama secara global untuk dapat mengungkap "kemana uang rakyat yang mereka rampas". Namun pengungkapan itu tidaklah mudah, mungkin saja para koruptor dillindungi oleh otoritas sebuah negara lain, perlu usaha yang komperehensif untuk dapat mengembalikan dan mengungkapkan tindakan korupsi tersebut.

Tata kelola pemerintahan pada tingkat lokal (pemerintah daerah) berada pada model tata kelola menuntut partisipasi warga yang aktif, melalui keterlibatan langsung atau tidak langsung (Fung, 2008; Michels \& Graaf, 2010; Tholen, 2015). Membangun kemitraan dan peningkatan kapasitas masyarakat merupakan fitur kunci dari reformasi kontemporer dalam sistem tata kelola dan manajemen (Farazmand, 2004). Demikian pula, tata kelola nasional diharuskan untuk mengikuti berbagai standar dan norma internasional secara global yang dibentuk secara kolektif (Kettl, 2000; UN, 2004; Xueliana \& Lu, 2016), melalui institusi supranasional seperti Perserikatan Bangsa-Bangsa dan badanbadan afiliasinya.

Dynamic governance, Neo dan Chen (2007:1) menjelaskan, dynamic governance is the key to success in a world undergoing accelerating globalization and unrelenting technological advancement. Tata kelola yang dinamis mencapai relevansi dan efektivitas saat ini dan masa depan melalui kebijakan yang terus-menerus menyesuaikan diri dengan perubahan lingkungan. Bisakah institusi pemerintah berkembang secara dinamis? Neo dan Chen (2007:1) kembali memberikan argumentasinya, dynamism is characterized by new ideas, fresh perceptions, continual upgrading, quick actions, flexible adaptations, and creative innovations. Bila institusi/birokrasi pemerintah yang selama ini kita kenal yang menghasilkan banyak sekali masalah (lihat lebih lanjut Caiden, 1991) ditambah dengan peraturan yang rigid, struktur birokrasi yang besar, prosedur yang berbelit, hierarkis yang panjang, perilaku para pejabat yang korup, dan tidak mungkin institusi/birokrasi pemerintah akan berkembang secara dinamis. Sebagai contoh, ketika jabatan sudah diperjual-belikan maka akan terjadi gelombang penyalahgunaan wewenang. Modus operandi yang sederhana dilakukan oleh para pejabat akan selalu sibuk dengan urusan anggaran, luncuran anggaran untuk menutupi "modal finansial" ketika dia membeli jabatan tersebut. Dan tidak akan mempunyai waktu untuk berpikir melakukan perubahan dan hanya menerima kondisi kerja yang sudah ada. Walaupun secara teoritis dan praktis anggaran adalah menu utama institusi pemerintah (birokrasi) dapat menjalankan tugasnya dengan baik (Pierre, 1995). Belum lagi intervensi politik yang berlebihan dalam birokrasi akan mengarah kepada eksploitasi aparatur birokrasi secara berlebihan.

Diperlukan langkah yang sistematik dan komprehensif untuk melakukan perubahan, kita patut berbangga ketika pemerintah melakukan open recruitment aparatur birokrasi sampai dengan jabatan tinggi untuk mencegah terjadinya jual beli jabatan. Tujuannya untuk melahirkan aparatur birokrasi yang berkualitas tinggi. Karena menyangkut model dan cara pemerintah untuk mencapai tujuan jangka menengah dan panjang diperlukan partisipasi pemangku kepentingan secara berkesinambungan antara pemerintah, sektor swasta, masyarakat madani, dan komunitas masyarakat dalam merumuskan setiap kebijakan serta pola partisipasi pemangku kepentingan itu sendiri yang mengarah kepada bentuk perubahan yang disepakati. Partisipasi ini penting dalam negara demokrasi untuk mengembalikan kepercayaan publik, walaupun partisipasi masyarakat belum tentu berkontribusi signifikan terhadap perubahan institusi pemerintah sebuah negara (Callahan, 2007; Cheema \& Rondinelli, 2007; Michels \& Graaf, 2010).

Institusi pemerintah (birokrasi) yang dinamis dapat meningkatkan pembangunan dan kemakmuran suatu negara (Neo \& Chen, 2007), dengan pola penyesuaian adaptif terhadap perubahan lingkungan sosio-ekonomi di mana orang melakukan transaksi bisnis dan pemerintah berinteraksi dengan berbagai kebijakan dan pengawasan sehingga dapat menimbulkan implikasi positif tidak hanya kepada pemerintah tapi terutama untuk kesejahteraan masyarakat. Dinamisme menyiratkan pembelajaran terus menerus, eksekusi cepat yang efektif, dan perubahan tanpa henti. Perubahan tanpa henti 
itu akan memberikan dampak kepada daya saing ekonomi dan pembangunan sosial budaya sebuah negara. Sebagai contoh Korea Selatan, negara maju ini begitu banyak menghasilkan berbagai bentuk terobosan dengan menjadikan budaya inovasi menjadi kebiasaan dalam berbagai penyelenggaraan aktivitas negara berbasis elektronik dan ditunjang dengan infrasruktur yang begitu baik (jaringan internet tercepat). Negara Jepang dengan budaya malu, ketika mereka dinyatakan bersalah maka tidak ada keraguan bagi mereka untuk mengundurkan diri dari jabatan.

Contoh dari kedua negara di atas, memberikan analitis bahwa budaya akan sangat memengaruhi setiap aktivitas kegiatan pemerintah. Neo dan Chen (2007:3) memberikan argumentasi tentang cara menjadi salah satu negara maju, foundation of cultural values and beliefs can work synergistically with strong organizational capabilities to create a dynamic governance system that enables continuous change. Itu sebabnya budaya sebuah negara sering terlupakan dan selalu terfokus kepada budaya dari luar yang dianggap merupakan hal yang terbaik untuk dijadikan sebuah pilihan, mungkin saja hal itu terjadi karena politik ekonomi luar negeri sebuah negara. Dalam konsep tata kelola pemerintah yang dinamis (dynamic governance) akan tercapai ketika kebijakan yang adaptif dijalankan. Kebijakan yang adaptif ini lebih merujuk kepada policy diffusion (Baybeck, Berry, \& Siegel, 2011; Gilardi, 2016). Neo dan Chen (2007) menulis landasan dynamic governance adalah budaya kelembagaan suatu negara yang ditunjukkan dengan tiga faktor kemampuan dinamis (dynamic capabilities) yaitu berpikir ke depan (thinking ahead), berpikir kembali (thinking again), dan berpikir sepanjang mengarah kepada pelaksanaan kebijakan yang adaptif (thinking across). Ada faktor pengungkit utama untuk mengembangkan dynamic governance yaitu orang yang cakap (able people) diisi oleh orang-orang yang cerdas, gesit, dan tangkas (agile people). Namun pengaruh yang menjadi perhatian serius adalah faktor lingkungan eksternal (external environment) yang akan memengaruhi sistem pemerintahan seperti masalah keamanan, kemiskinan, politik, yang menimbulkan ketidakpastian perubahan.

Open government, gerakan ini menjadi populer setelah adanya Memorandum on Transparency and Open Government oleh Pemerintahan Barrack Obama pada tahun 2009, dan diikuti oleh peluncuran data. gov.uk oleh pemerintah Inggris pada tahun 2010. Kemudian mulailah muncul portal data pemerintah yang terus menyebar, dibuat oleh pemerintah dan tim independen multilateral bekerjasama dengan pemerintah yang bergerak untuk mengembangkan inisiasi data terbuka pemerintah. Wirtz dan Birkmeyer (2015:12) mendefinisikan open government sebagai a multilateral, political and social process, which includes in particular transparent, collaborative and participatory action by government and administration. Open government didefinisikan sebagai tindakan dari transparansi, partisipasi, dan kolaborasi (Obama, 2009). Di Indonesia gerakan open government ini telah direspon oleh pemerintah dengan Undang-Undang Nomor 14 Tahun 2008 Tentang Keterbukaan Informasi Publik. Bila melihat data yang dikeluarkan oleh Komisi Informasi Pusat terdapat sengketa yang diajukan oleh individu dan kelompok masyarakat. Biasanya sengketa yang muncul disebabkan oleh tidak adanya transparansi data pemerintah yang semestinya dapat dikonsumsi oleh publik. Beberapa studi juga menyebutkan bahwa transparansi dalam penyelenggaraan pemerintah (prinsip good governance) tidak begitu baik pelaksanaannya di beberapa negara berkembang (Ferreira, 2008; Zimmerman, 2014).

Beberapa tahun terakhir, open government telah menjadi gerakan penting di antara pemerintahan di seluruh dunia. Misalnya, dari sisi keuntungan open government lebih memudahkan masyarakat untuk akses data dan aktivitas pemerintah, perundangundangan dan kebijakan pemerintah yang dapat diperoleh dengan mudah, data terbuka terkait erat dengan pembagian informasi pemerintah yang dapat digunakan oleh publik untuk berbagai tujuan. Namun kebanyakan para ahli berargumentasi potensi manfaat open government dapat merangsang transparansi, akuntabilitas, meningkatkan partisipasi masyarakat, dan merangsang pertumbuhan ekonomi (Wirtz, Weyerer, \& Rosch, 2017), dan juga sebagai upaya untuk memerangi tindakan korupsi (Kim, Kim, \& Lee, 2009).

Intisari dari pembahasan fokus perubahan tata kelola pemerintah antara sound governance, dynamic governance, dan open government terlihat pada Gambar 1.

Konsep sound governance, dynamic governance, dan open government merupakan cara baru dalam sistem tata kelola lokal, nasional, regional, dan internasional. Sound governance terkait secara langsung atau tidak langsung yang terhubung dengan berbagai sistem global untuk memeriksa opsi, solusi, dan masalah tata kelola pemerintah. Artinya konsep ini menekankan kolaborasi dengan berbagai sistem global dan kerja sama antara setiap negara yang menyetarakan hak setiap negara baik negara maju maupun negara berkembang sehingga eksploitasi dan kapitalisasi ekonomi tidak terjadi lagi. Sedangkan dynamic governance konsep yang menekankan untuk memerhatikan faktor eksternal lingkungan kebijakan. 


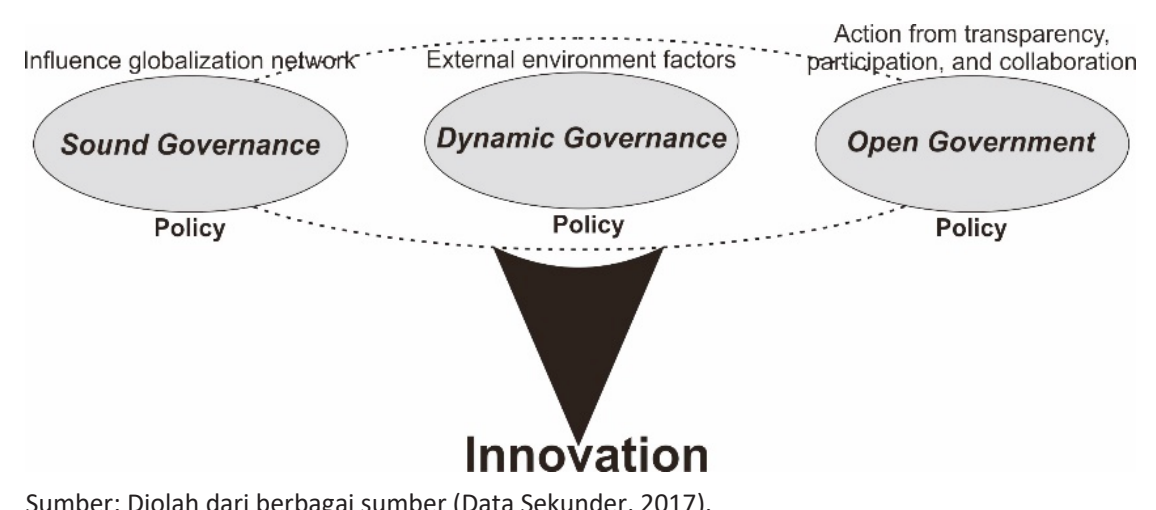

Sumber: Diolah dari berbagai sumber (Data Sekunder, 2017).

Gambar 1. Fokus Perubahan Tata Kelola Pemerintah

Adaptasi kebijakan bukan sekadar reaksi yang pasif terhadap tekanan eksternal namun pendekatan proaktif terhadap inovasi, kontekstualisasi, dan eksekusi. Inovasi kebijakan berarti gagasan yang baru dan segar, bereksperimen dan dimasukkan ke dalam kebijakan untuk mencapai hasil yang lebih baik dan berbeda. Namun bukan hanya tentang ide baru dalam bentuk desain kontekstual tapi juga eksekusi kebijakan yang membuat pemerintahan dinamis menjadi kenyataan (Neo \& Chen, 2007). Sedangkan open government lebih menekankan kepada prinsip transparansi tinggi data pemerintah untuk dapat dikonsumsi oleh publik dengan cara memanfaatkan teknologi informasi. Open government lebih mirip kepada penerapan sistem elektronik dalam berbagai aktivitas pemerintah. Namun partisipasi masyarakat menjadi hal yang diperhatikan secara bersama dengan pemerintah. Ikut mengawasi aktivitas pemerintah, menganggap masyarakat lebih bermakna dan ikut serta dalam pembangunan nasional.

Ketiga konsep ini berujung kepada penerapan "inovasi pemerintah". Idealnya dari sisi tujuan dalam lingkup organisasi pemerintah, inovasi dapat menekan masalah korupsi, kolusi, dan nepotisme (Klareskov \& Nikolov, 2007), berkontribusi terhadap kinerja dan efektivitas organisasi (Damanpour, 1991). Lingkup pelayanan inovasi dipercaya akan meningkatkan kualitas pelayanan lebih efektif, efisien dan merupakan cara untuk mengatasi masalah organisasi pemerintah dalam menghadapi tantangan dari masyarakat yang semakin komplek (Vries, Bekkers, \& Tummers, 2015; McLaughlin \& Kennedy, 2016), memaksimalkan sumber daya manusia dan mengembalikan kepercayaan publik terhadap pemerintah dengan mendorong upaya berkelanjutan (Alberti \& Bertucci, 2007).

Dinamika berbagai sistem tata kelola pemerintahan ini menyajikan peluang besar bagi penelitian ilmu sosial untuk meningkatkan pengetahuan dan memperbaiki kinerja pemerintahan (Farazmand, 2004).

\section{Perbandingan Tata Kelola Pemerintahan}

Konsep tata kelola pemerintah dari waktu ke waktu terus mengalami perkembangan sesuai dengan dinamisme perubahan jaman yang terus berkembang. Perbandingan tata kelola itu menyiratkan pemikiran lebih kepada para praktisi untuk memunculkan konsep yang lebih baik dari konsep tata kelola pemerintah yang telah ada walaupun masing-masing pendekatan memiliki konsekuensi positif dan negatif. Sound governance misalnya, konsep ini muncul akibat banyaknya kritikan dari negara berkembang yang menganggap good governance adalah sebuah konsep kapitalisme negara maju (negara donor). Namun dominasi negara maju dalam pusaran globalisasi membuat beberapa aliansi negara berkembang terbentuk. Uni Afrika, Perhimpunan Negara Islam, ASEAN, semua itu bertujuan untuk filterisasi hegemoni negara maju terhadap negara-negara berkembang. Banyak negara saat ini memerhatikan permintaan informasi, teknologi dan keterampilan kolektif secara global. Permintaan itu tercermin dalam beberapa kasus misalnya korupsi, asap akibat kebakaran, kemiskinan, kriminal dan sebagainya. Untuk mengatasi beberapa kasus itu diperlukan kerjasama antara negara sebagai upaya pencegahan. Namun kerjasama itu tidak mengintervensi kedaulatan dan sistem negara masing masing, juga mencakup fitur normatif, teknis dan rasional dari tata kelola pemerintahan yang baik. Lain halnya dengan konsep good governance yang mengintervensi suatu negara dengan kebijakan yang harus dipatuhi.

Bila konsep sound governance menekankan tata kelola yang terintegrasi dengan dunia internasional, konsep dynamic governance memberi penekanan pada adaptasi tata kelola pemerintah terhadap perubahan lingkungan. Kebiasaan buruk yang selalu diperlihatkan terutama pemerintah daerah, seperti pengangkatan seseorang aparatur birokrasi (posisi untuk menduduki jabatan) sering terjadi praktek jual beli, menempatkan seorang pimpinan atas dasar paternalistik, sebagai imbalan dukungan politik 
dan bukan berdasarkan kompetensi seseorang (merit system). Namun hal ini telah diantisipasi oleh pemerintah dengan mengeluarkan kebijakan tentang Manajemen Aparatur Sipil Negara dan rekruitmen Aparatur Sipil Negara dengan cara yang lebih modern, transparansi dan open recruitment. Bila masih ada pimpinan dalam sebuah institusi pemerintah dipimpin oleh orang yang tidak cakap, cerdas, dan gesit maka dynamic governance tidak akan pernah terlaksana dan begitu juga sebaliknya.

Salah satu pilar dari open government adalah transparansi, meskipun transparansi sering disebut sebagai keuntungan dari open government (Zuiderwijk \& Janssen, 2014). Open government juga belum tentu menghasilkan transparansi (Bannister \& Connolly, 2011). Sebagai contoh, dalam konsepsi pemerintahan terbuka segala data pemerintah seharusnya dapat dipantau dan dimiliki oleh masyarakat, walaupun kebijakan pemerintah mengatur mana data yang boleh dipublikasikan dan mana yang tidak. Namun yang sering terjadi oknum pemerintah dengan sadar atau tidak menghalangi masyarakat untuk memiliki data tersebut. Ada ketakutan bagi mereka untuk mempublikasikan, secara logis bila kita tidak berbuat salah mengapa harus takut untuk memberikan datadata tersebut kepada masyarakat. Mungkin saja masyarakat membutuhkan data tersebut untuk penelitian misalnya. Bagi kelompok masyarakat seperti lembaga swadaya masyarakat (LSM), wartawan, data tersebut juga dapat digunakan untuk hal positif seperti pengawasan kinerja pemerintah oleh civil society. Negatifnya data itu digunakan untuk memeras oknum-oknum pemerintah. Artinya prinsip transparansi menjadi gugur ketika data pemerintah tidak dapat diperoleh dengan mudah dan digunakan oleh publik.

Memperjelas perbandingan di antara konsep tata kelola pemerintahan tersebut dapat dilihat pada Tabel 1.

Karakteristik kunci dari semua konsep di atas adalah klaim untuk menolak bentuk tradisional pemerintahan otoriter dan birokratis. Kejadian ini akan sering terjadi apabila kualitas sumber daya manusia tidak menunjukkan perubahan. Konsep/ teori yang baru muncul berdasarkan konsep/teori yang sudah ada. Namun sebuah konsep akan lebih mudah dikenal dan populer apabila konsep/teori tersebut dimunculkan oleh para institusi dan sering digunakan. Ketersediaan literatur yang banyak akan lebih mudah orang untuk membaca dan memahami. Sebagaicontoh, konsep soundgovernance tidakbegitu populer karena ketersediaan literatur yang terbatas dan implementasinya dalam aktivitas pemerintah dan organisasi sangat jarang terungkap. Para pakar lebih menyukai menggunakan makna sustainability, development dari pada makna sound. Intinya sama dan bercerita tentang kerjasama internasional dalam mengembangkan dan membangun tata kelola yang baik secara berkelanjutan dalam setiap aktivitas pemerintah.

\section{Kelemahan dan Kekuatan Konsep Tata Kelola Pemerintahan}

Memahami perubahan telah menjadi salah satu tantangan terpenting bagi pemerintahan kontemporer. Mulai dari beberapa kondisi global seperti krisis ekonomi, kemiskinan, korupsi, dan kapitalisme ekonomi negara maju, menunjukkan berbagai konsep muncul untuk mengatasi hal tersebut. Bagi pemerintah kontemporer konsep tata kelola yang baik bukanlah merupakan fenomena baru. Meskipun pergeseran dari pemerintahan ke pemerintahan berikutnya kadang-kadang dipresentasikan sebagai sebuah terobosan dramatis dari masa lalu, dengan media pemerintah, birokrasi, undang-undang, dan kebijakan untuk mengimplementasikan rencana/janji kampanye mereka, namun harus dipahami dengan lebih halus dengan mengabaikan presentasi terobosan yang sudah ada.

Bentuk tradisional tata kelola pemerintah muncul pada era tahun 80 -an yang didasari pada beberapa kasus yang lebih dominan terjadi pada negara berkembang. Berbagai disiplin ilmu berkontribusi untuk melahirkan konsep tata kelola pemerintah yang saat ini kita kenal. Berbagai tantangan setiap negara membutuhkan energi yang lebih untuk dapat mengembangkan tata kelola pemerintah menjadi lebih baik lagi. Dalam konteks tantangan tersebut,

Tabel 1. Perbandingan Konsep Tata Kelola Pemerintah

\begin{tabular}{lll}
\hline & Comparative & Focus \\
\hline Sound Governance & $\begin{array}{l}\text { Sustainability Conceptualizing (Lafferty, 2004; } \\
\text { Lange et al., 2013). }\end{array}$ & Global collaboration network, and innovation. \\
\hline Dynamic Governance & $\begin{array}{l}\text { Knowledge management theory (Polanyi, 2005; } \\
\text { Nonaka \& Krogh, 2009). }\end{array}$ & Tacit and explicit knowledge, and innovation. \\
\hline Open Government & Transparency theory (Finkelstein, 2000; Oliver, 2004). & Transparency, and innovation. \\
\hline
\end{tabular}

Sumber: Diolah dari berbagai sumber (Data Sekunder, 2017). 
menilai bentuk-bentuk baru (termasuk metode) yang dibandingkan dengan standar tata kelola yang lama tidak tepat lagi dan berisiko menghalangi perkembangan model pemerintahan modern untuk jangkauan yang lebih besar dan luas. Halkier, KatzGerro dan Martens (2011) menulis, konsep/teori dengan praktek sangat berbeda, dan bisa saja konsep/teori memiliki kekuatan dan kelemahan. Untuk menjelaskan kekuatan dan kelemahan konsep tata kelola pemerintahan tersebut dapat dilihat pada Tabel 2.

Sebagai contoh, beberapa konsep tata kelola pemerintah itu telah termanifestasi secara global. Seperti konsep sound governance diadopsi oleh universitas sebagai landasan untuk bekerjasama dengan universitas internasional dan berupaya untuk menjadi organisasi yang unggul, menumbuhkan daya saing tingkat nasional dan internasional. Namun kendala yang bersifat politik, ekonomi, maupun budaya menjadi beberapa masalah penghambat inisiasi sound governance (Ridla \& Kusuma, 2016). Singapura menerapkan konsep dynamic governance dalam aktivitas pemerintah, mereka melakukan modernisasi birokrasi, mengadopsi merit system untuk menempatkan para pejabat negara, sosialisasi dan edukasi secara berkesinambungan untuk membangun masyarakat madani yang lebih kritis dan meningkatkan kapasitas kolaborasi antara pemerintah sebagai regulator dan pengawas terhadap setiap kegiatan swasta yang akan berkontribusi terhadap kesejahteraan rakyat (Neo \& Chen, 2007). Amerika Serikat dengan open government, namun inisiasi ini tidak selalu positif dalam pelaksanaanya bila dilakukan di tempat berlainan. Seperti misalnya Belanda mengadopsi open government, namun terdapat efek negatif dari penerapannya. Efek negatif yang timbul adalah resiko untuk melanggar undang-undang atau peraturan lain. Implikasi yang timbul apabila data dibuka maka akan memberikan situasi yang berbeda karena bertentangan dengan beberapa peraturan (seperti hukum perlindungan data). Efek negatif lain adalah salah tafsir dan penyalahgunaan, orang dengan pengetahuan yang terbatas untuk menafsirkan data akan cenderung menghasilkan kesimpulan yang salah dari analisis data yang mereka lakukan. Dan data ini juga akan digunakan oleh sekelompok orang untuk memeras para pejabat negara demi keuntungan pribadi dan kelompok (Zuiderwijk \& Janssen, 2014).

Salah satu elemen tata kelola pemerintahan sering dibahas adalah partisipasi masyarakat. Berbagai studi mengungkapkan partisipasi masyarakat belum tentu memberikan manfaat lebih dalam tata kelola pemerintah. Pada negara berkembang seperti Afrika partisipasi masyarakat sangat dibatasi terutama bagi kaum miskin alasannya karena kaum miskin kurang memberikan kontribusi dalam penyelenggaraan pemerintah. Kejadian di negara Amerika Latin, partisipasi masyarakat tidaklah selalu yang paling penting untuk menciptakan tata kelola pemerintah yang baik dalam desentralisasi. Di Timur Tengah pemerintah membiarkan partisipasi masyarakat bukan berarti mereka akan mendorong lebih kuat secara nyata partisipasi masyarakat dalam mengawasi pemerintah (Cheema \& Rondinelli, 2007).

Cheema dan Rondinelli (2007:9) menjelaskan, decentralization and citizen participation is conditioned by complex political, historical, social, and economic factors that differ in strength and importance among and within countries. Faktor politik, sejarah, sosial, dan ekonomi yang memengaruhi partisipasi masyarakat dalam sebuah negara. Walaupun partisipasi masyarakat ini menjadi berdebatan tapi sisi baiknya membuat warga negara menjadi lebih bermakna untuk negara. Sepertinya kasus di negara berkembang di atas hampir mirip dengan kondisi di Indonesia, keikutsertaan masyarakat belum begitu terlihat kental dan ikut mengawasi berjalannya pemerintahan yang baik, walaupun hak dan kewajiban warga negara dijamin

Tabel 2. Kekuatan dan Kelemahan Konsep Tata Kelola Pemerintah

\begin{tabular}{lll}
\hline Sound Governance & $\begin{array}{l}\text { Kekuatan } \\
\text { Kerja sama internasional akan lebih mudah } \\
\text { negara atau organisasi. }\end{array}$ & $\begin{array}{l}\text { Kurang populer dalam implementasinya untuk aktivitas } \\
\text { pemerintah dan organisasi. }\end{array}$ \\
\hline Dynamic Governance & $\begin{array}{l}\text { Dorongan untuk terus meningkatkan tacit } \\
\text { dan explicit knowledge. }\end{array}$ & $\begin{array}{l}\text { Akan tidak bermakna apabila birokrasi yang korup, } \\
\text { spoil system, nepotisme dan masyarakat belum } \\
\text { sepenuhnya demokratis untuk mengawasi aktivitas } \\
\text { pemerintah (Gulbrandsen, 2014; Rajan, 2017). }\end{array}$ \\
\hline Open Government & $\begin{array}{l}\text { Transparansi, dan peluang melibatkan } \\
\text { masyarakat dalam setiap aktivitas dan } \\
\text { pengawasan pemerintah menjadi lebih besar. }\end{array}$ & $\begin{array}{l}\text { Keterbukaan belum tentu akan berkontribusi signifikan } \\
\text { terhadap transparansi (Shkabatur, 2013; Zuiderwijk \& } \\
\text { Janssen, 2014). }\end{array}$ \\
\hline
\end{tabular}

Sumber: Diolah dari berbagai sumber (Data Sekunder, 2017). 
oleh undang-undang. Dalam pandangan administrasi publik, partisipasi masyarakat mengacu pada peran masyarakat ikut serta dalam pengambilan keputusan administratif dan turut serta dalam mengawasi pelayanan publik yang dihantarkan oleh pemerintah (Callahan, 2007; Fung, 2008). Partisipasi masyarakat akan menghasilkan nilai yang dapat meningkatkan efektivitas kegiatan pemerintah. Namun, partisipasi masyarakat hanya akan memberikan manfaat apabila warga di sebuah daerah kritis dan demokratis.

\section{Positif dan Negatif Konsep Sound Governance,} Dynamic Governance, dan Open Government

Memulai diskusi pada bagian ini terlebih dahulu peneliti menghadirkan dimensi, elemen dan pilar dari konsep tata kelola pemerintahan yang berasal dari berbagai pembahasan pada bagian sebelumnya, dapat dilihat pada Tabel 3.

Seperti yang telah diuraikan sebelumnya, intisari dari konsep di atas adalah "inovasi" pemerintah. Namun kita dapat membahas beberapa efek positif dan negatif dari dimensi, elemen, dan pilar dari konsep tersebut yang mempunyai kesamaan, seperti:

\section{Transparency}

Transparansi dianggap sebagai cara untuk membuka berbagai hal dari aktivitas pemerintah, bertujuan untuk mengawasi setiap aktivitas pemerintah dengan mudah. Konsep transparansi pada umumnya dipegang dan diinginkan untuk dilakukan. Gagasan panjang transparansi ini telah mendapatkan tempat lebih lanjut dengan kemunculan pemerintahan berbasis elektronik (e-government). Transparansi juga seperti dua bilah mata uang yang berlainan. Pada keadaan tertentu transparansi menjadi positif dalam mendukung aktivitas pemerintah untuk menghadirkan tata kelola pemerintah yang baik, di sisi lain bertindak lebih ke arah negatif. Dengan perkembangan teknologi yang semakin pesat yang menembus batas antara pemerintah dan masyarakat, transparansi selalu diharapkan bermanfaat tinggi dengan menggunakan teknologi (Bannister \& Connolly, 2011). Untuk memperdalam pemahaman untuk membangun argumentasi yang kuat tentang positif dan negatif transparansi, diilustrasikan dalam bentuk Gambar 2:

Yang pertama adalah hak publik untuk mengetahui (public right to know). Dikebanyakan negara berkembang sumber utama anggaran negara berasal dari pungutan pajak yang dilakukan pemerintah kepada rakyatnya. Namun dengan sangat mudah dapat dipahami orang-orang yang menjalankan aktivitas negara dibayar (digaji) dari pajak yang dipungut. Sudah seharusnya masyarakat (rakyat) mempunyai hak mengetahui segala aktivitas negara yang menggunakan uang rakyat. Hak ini telah tertanam dalam tindakan keterbukaan informasi publik di banyak negara dan tersirat dalam konsep akuntabilitas (Callahan, 2007). Namun akuntabilitas tanpa transparansi menjadi tidak bermakna (Shkabatur, 2013), karena aktivitas pemerintah tidak dapat dimintai pertanggungjawabannya. Dan bahkan di negara demokratis harus ada anggapan yang kuat untuk melakukan transparansi (lihat lebih lanjut Stiglitz, 1999). Transparansi tidak hanya dibahas dalam ilmu administrasi publik sebagai sebuah paradoks, transparansi juga dikaji dalam literatur lain seperti kedokteran dan studi keuangan. Namun, transparansi belum tentu sesuai dengan beberapa aspek dari apa yang dianggap sebagai tata kelola pemerintahan yang baik. Lebih halus lagi, ada kemungkinan transparansi tidak sesuai dengan bentuk pemerintahan yang baik lainnya. Sebagai contoh, open government bercerita tentang informasi aktivitas pemerintah yang dibuka untuk

Tabel 3. Konsep Tata Kelola Pemerintah

\begin{tabular}{|c|c|c|}
\hline Sound Governance & Dynamic Governance & Open Government \\
\hline Dimensions & Elements & Three Pillars \\
\hline $\begin{array}{l}\text { 1. Process; } \\
\text { 2. Structure; } \\
\text { 3. Cognition and Value; } \\
\text { 4. Constitution; } \\
\text { 5. Organization and Institution; } \\
\text { 6. Management and Performance; } \\
\text { 7. Policy; } \\
\text { 8. Sector; } \\
\text { 9. International and Globalization Forces; } \\
\text { 10. Ethics, Transparency, and } \\
\text { Accountability. }\end{array}$ & $\begin{array}{l}\text { 1. Culture; } \\
\text { Institutional culture } \\
\text { 2. Capabilities; } \\
\text { Thinking ahead, thinking again, thinking across } \\
\text { 3. Change; } \\
\text { Adaptive policy } \\
\text { (Neo \& Chen, 2007:13) }\end{array}$ & $\begin{array}{l}\text { 1. Transparency; } \\
\text { 2. Collaborative; } \\
\text { 3. Participatory. } \\
\text { (Obama, 2009; Gasco, 2015; } \\
\text { Wirtz \& Birkmeyer, 2015) }\end{array}$ \\
\hline (Farazmand, 2004:13) & & \\
\hline
\end{tabular}

Sumber: Diolah dari berbagai sumber (Data Sekunder, 2017). 


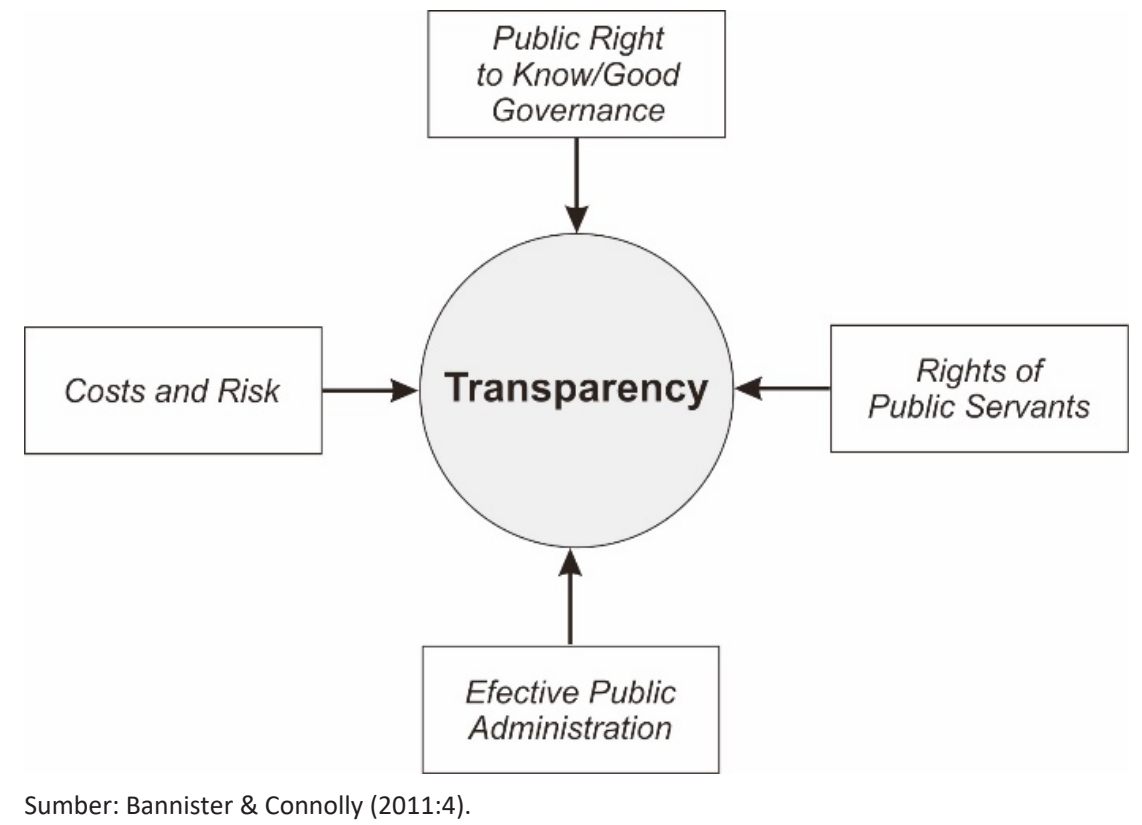

Gambar 2. Forces Influencing Policy on Transparency

publik. Positifnya dengan membuka informasi aktivitas pemerintah, masyarakat lebih leluasa ikut dalam pengawasan pemerintah, namun di beberapa kondisi transparansi ini menjadi negatif dan akan membahayakan stabilitas keamanan negara dan situasi politik seperti indikasi korupsi para pejabat elit negara yang dilindungi oleh tirani kekuasaan (kasus panama paper). Dalam kasus negatif ini syarat transparansi menjadi gugur.

Kedua, biaya dan risiko (cost and risk), pergeseran aktivitas transparansi dari tradisional sampai modern menyebabkan banyak pemerintah menerapkan aktivitas pemerintah berbasis elektronik salah satu tujuannya untuk memenuhi syarat transparansi (e-Budgeting, e-Kinerja, LPSE, e-Transparansi, e-Data, dan lain sebagainya). Walaupun aktivitas pemerintah berbasis elektronik tidak bisa menghindari unsur biaya yang besar dan masalah. Keuntungannya, aparatur birokrasi (public servants) lebih mudah melakukan tugasnya dengan baik. Negatifnya aktivitas berbasis elektronik mendapat ancaman dari tindakan hacking apabila sistem keamanannya rendah, masalah hukum tentang privatisasi seseorang, kualitas sumber daya manusia yang rendah akan memungkinkan tidak disiplin dalam input data. Karena dalam konsepsi open government ketepatan data yang dipublikasikan dan kualitas data menjadi salah satu hal terpenting.

Akhirnya, ada hak aparatur birokrasi untuk melindungi privasi pribadi dan kebebasan di tempat kerja dan kemampuan administrasi publik untuk beroperasi secara efektif (effective public administration). Di kasus tertentu data pemerintah menjadi bahan pertengkaran di antara kelompok masyarakat dengan pemerintah. Hal ini dibuktikan dengan pengaduan masyarakat kepada Komisi Informasi Pusat (KIP Republik Indonesia) tentang keterbukaan informasi publik pemerintah.

\section{Policy}

Dye (2013:3) memberikan argumentasi, public policy is whatever governments choose to do or not to do. Argumentasi ini terkait dengan apa yang pemerintah lakukan atau tidak melakukan sama sekali, mengapa pemerintah melakukannya, dan apa bedanya. Pemerintah melakukan banyak hal, pemerintah mengatur konflik di dalam masyarakat, pemerintah mengorganisir masyarakat untuk melakukan konflik dengan masyarakat lain, pemerintah mendistribusikan beragam penghargaan simbolis dalam bentuk layanan material kepada anggota masyarakat, dan pemerintah mengambil uang dari masyarakat paling sering dalam bentuk pajak. Dengan demikian, kebijakan publik dapat mengatur perilaku, mengatur birokrasi, mendistribusikan keuntungan, mengambil pajak atau semua hal ini sekaligus (Dye, 2013).

Gagasan inovasi birokrasi juga diatur dalam Undang-Undang Republik Indonesia Nomor 23 Tahun 2014 tentang Pemerintah Daerah pada pasal 386 ayat 1 . Tapi sepertinya kebijakan pemerintah ini masih belum dianggap sebagai "perintah" untuk dilaksanakan secara penuh terutama oleh pemerintah daerah. Dalam pandangan difusi kebijakan (policy diffusion) menunjukkan aktivitas pembuatan kebijakan dapat terjadi melalui proses pilihan kebijakan yang dibuat di tempat dan waktu tertentu dipengaruhi oleh pilihan kebijakan yang dibuat di tempat lain atau sederhananya "pemerintah" dapat merumuskan kebijakan bersumber dari kebijakan yang telah sukses di tempat lain dengan cara melakukan benchmarking 
(studi banding) ke daerah lain yang berhasil melakukan berbagai inovasi (Volden, Ting, \& Carpenter, 2008; Gilardi, 2016). Sisi positifnya benchmarking akan menjadi bahan terpenting untuk merumuskan kebijakan dalam melakukan inovasi sebagai derivate kebijakan yang sudah ada. Lebih rinci lagi, kebijakan yang sukses di daerah lain bisa diadopsi menjadi rujukan utama namun harus mengembangkan inovasi yang telah ada menjadi lebih efektif lagi atau sebagai bahan untuk mencari ide baru inovasi yang lebih murah namun kaya manfaat. Negatifnya benchmarking dilakukan, tapi tidak ditindaklanjuti dan hanya sekedar menghabiskan anggaran negara yang tidak bermanfaat. Sebagai contoh, terkadang pemerintah daerah ingin melakukan studi banding tidak memperlihatkan kebutuhan apa yang tepat untuk diadopsi. Modus yang sering dilakukan dengan cara memilih daerah yang jauh tetapi kenyataannya daerah yang dekat yang memiliki budaya hampir serupa yang telah sukses bukan menjadi suatu pilihan. Logisnya dengan jauhnya jarak benchmarking tersebut akan membutuhkan anggaran yang besar pula, dan modus ini yang dimanfaatkan oleh sebahagian kalangan untuk tujuan plesiran bersama keluarga.

\section{Cognition and Value (Capabilities Knowledge)}

Pengetahuan merupakan interaksi antara tacit dan explicit knowledge (Polanyi, 2005). Dalam pandangan knowledge management interaksi tersebut sebagai ungkapan yang merujuk kepada sebuah strategi, teknik, sistem yang digunakan oleh individu atau kelompok dengan membuat proses pengetahuan itu tersedia dan memperkuat pengetahuan yang dibuat oleh individu atau kelompok sebelumnya (Nonaka \& Krogh, 2009). Bagaimana pengetahuan itu didapat dan diterapkan membutuhkan media pengetahuan formal maupun informal. Pengetahuan tacit dan explicit knowledge secara inheren tidak dapat dipisahkan. Tacit knowledge merujuk kepada jenis pengetahuan yang sulit untuk dikatakan sebagai pengetahuan dan mengacu kepada intuitif yang berbasis pengalaman. Pengetahuan yang bersifat tacit menggerakkan bahasa, science, pendidikan, manajemen, dan hubungan antara manusia dengan benda (Collins, 2010). Explicit knowledge, jenis pengetahuan manusia yang dapat dikomunikasikan melalui tanda, ikon, kode dan merupakan interaksi antara objek fisik yang sering disebut sebagai entitas (Collins, 2010). Biasanya pengetahuan ini mudah diartikulasikan dalam bentuk komunikasi verbal atau buku.

Sebagai contoh, ketika tacit knowledge individu (mulai dari pimpinan puncak sampai dengan street level bureaucract) seperti gagasan, persepsi, cara pikir, wawasan, keahlian, dan pengalaman "rendah" akan menjadi bencana bagi birokrasi pemerintah untuk melaksanakan berbagai inovasi. Inovasi bukan hanya bercerita tentang menemukan ide-ide baru namun inovasi harus didukung oleh wawasan yang tinggi dan menampilkan sikap serving, empowering, enabling dan pada akhirnya akan menumbuhkan budaya inovasi yang akan membantu menerjemahkan setiap inovasi yang diadopsi (McLaughlin \& Kennedy, 2016). Dan sebaliknya ketika tacit knowledge individu "tinggi" akan memberikan keuntungan untuk meningkatkan kinerja organisasi. Kurangnya fokus pada tacit knowledge secara langsung akan berdampak terhadap berkurangnya kemampuan untuk melakukan inovasi dan daya saing yang berkelanjutan (Nonaka \& Krogh, 2009). Contoh lain pentingnya tacit knowledge dalam tata kelola pemerintah seperti sound governance, dynamic governance, dan open government menunjukkan pentingnya pengetahuan yang tinggi dari setiap individu. Dan tidak akan berhasil menerapkan tata kelola pemerintah itu apabila dijalankan oleh orangorang yang minim pengetahuan, tidak cerdas, dan tidak gesit. Namun tacit knowledge yang rendah juga diproduksi oleh penempatan pejabat yang tidak berkompetensi. Modus yang telah terungkap adalah jual beli jabatan, mengutamakan sifat paternalistik, dan besarnya intervensi politik dalam birokrasi. Para elit politik mencoba memengaruhi aktivitas birokrasi untuk kepentingan politik, sisanya para aparatur birokrasi dan sumber daya menjadi eksploitasi permainan para elit politik dan birokrasi hanya dijadikan permainan, oleh Robert Michels yang ia sebut sebagai oligarchy (Tolbert, 2010).

\section{KESIMPULAN}

Model atau konsep tata kelola pemerintahan yang telah diuraikan sebelumnya menghadirkan cara berpikir pemerintahan, dan administrasi baru, filosofi baru, dan pendekatan baru yang memperluas keterlibatan warga negara, menampung pendapat mereka. Membawa ke bidang partisipasi masyarakat sipil dan organisasi non-pemerintah ke dalam aktivitas pemerintahan serta menumbuhkan prinsip transparansi yang tinggi. Untuk menerapkan konsep tata kelola pemerintahan tersebut perlu dukungan berbagai aspek utama seperti regulasi pemerintah yang mendukung, kompetensi individu yang unggul, serta iklim organisasi yang baik.

Evolusi yang dialami dari berbagai konsep tata kelola pemerintahan mulai dari good governance, sound governance, dynamic governance, sampai open government merupakan sebuah konsep rujukan untuk menutupi kelemahan dari konsep 
sebelumnya. Namun dalam penerapannya di antara tempat berbeda sering sekali menemui kegagalan. Tidak seluruhnya dimensi, elemen atau pilar sebuah konsep dapat terlaksana dengan baik. Seperti konsep dynamic governance, konsep ini lahir dilatarbelakangi dari berbagai keunggulan negara Singapura seperti teknologi, sumber daya manusia, kebijakan pemerintah, sistem politik yang stabil, birokrasi yang bersih, masyarakat yang sudah demokratis. Konsep ini akan tidak bermakna apabila dilakukan pada tempat yang sumber daya manusia masih rendah, birokrasi yang korup, intervensi politik yang berlebihan, tidak adanya merit sistem, dan tidak terdapat teknologi terkini. Tata kelola pemerintah seperti apa pun bentuknya menyiratkan untuk menolak berbagai bentuk aktivitas pemerintah yang didasari kepada orientasi kekuasaan. Open government juga menjadi tidak bermakna apabila transparansi tidak terlaksana dengan baik. Dalam kondisi tertentu transparansi dapat mengancam stabilitas politik sebuah negara yang akan dimanfaatkan oleh beberapa kelompok untuk tujuan tertentu. Di sisi lain partisipasi masyarakat belum dianggap sebagai kekuatan positif untuk merumuskan setiap tindakan dan kebijakan pemerintah. Beberapa kasus yang telah dibahas sebelumnya juga menunjukkan partisipasi masyarakat tidak memberikan arti yang signifikan dalam memberikan pemikiran yang dapat memperbaiki kinerja dan kebijakan pemerintah. Oleh sebab itu, beberapa ahli dan praktisi mengklaim inovasi sebagai jawaban atas masalah yang dihadapi oleh pemerintah dengan mengutamakan prinsipprinsip tata kelola yang baik sebagai sebuah konsep yang logis dan akan sangat mungkin diterapkan.

Saran yang dapat diajukan sebagai konsekuensi dari pembahasan dalam artikel penelitian ini adalah pertama bagi pemerintah, dibutuhkan usaha yang lebih untuk mempertimbangkan konsep apa yang harus diadopsi dan sesuai. Konsep apapun yang diadopsi harus memerhatikan kualitas sumber daya manusia yang handal didukung oleh kebijakan pemerintah yang selalu adaptif dalam menyikapi setiap perubahan lingkungan seperti perubahan dinamika politik, teknologi terkini, dan sosial budaya masyarakat. Kedua bagi masyarakat, penerapan konsep tata kelola pemerintahan apapun yang diadopsi menjadi pintu untuk lebih aktif dalam pengawasan aktivitas pemerintah, mampu memberikan pendapat sebagai bahan pertimbangan perumusan kebijakan pemerintah, dan sebagai jalan untuk lebih kritis dan demokratis dalam menyikapi kebijakan pemerintah. Akhirnya bagi peneliti lain, artikel penelitian ini bisa menjadi dasar untuk mengungkapkan berbagai konsekuensi yang ditimbulkan oleh tata kelola pemerintahan yang diadopsi dengan melihat dari sudut pandang keilmuan yang berbeda.

\section{DAFTAR PUSTAKA}

\section{Buku}

Alberti, A., \& Bertucci, G. (2007). Innovation in governance and public administration: Key issues and perspectives. Dalam Department of Economic and Social Affairs (Ed.). Innovations in governance in the Middle East, North Africa, and Western Balkans: Making governments work better in the mediterranean region (h.3-12). New York: United Nations.

Barnett, E., \& Thomas, J. (2009). Methods for the synthesis of qualitative research: A critical review. London: Social Science Research Unit Institute of Education.

Callahan, K. (2007). Elements of effective governance: Measurement, accountability and participation. Boca Raton, FL: Taylor \& Francis Group.

Cheema, G. S., \& Rondinelli, D. A. (2007). Decentralizing Governance: Emerging Concept and Practice. Washington D.C: Brookings Institution Press.

Collins, H. (2010). Tacit and explicit knowledge. Chicago: The University of Chicago Press.

Dye, T. R. (2013). Understanding public policy $\left(14^{\text {th }}\right.$ ed.). Upper Saddle River, NJ: Pearson Education.

Farazmand, A. (2004). Sound governance: Policy and administrative innovations. Westport, CT: Praeger Publishers.

Finkelstein, N. D. (2000). Introduction: Transparency in Public Policy. Dalam N. D. Finkelstein, Transparency in Public Policy: Great Britain an the United State (h. 1-9). Houndmills: Palgrave Macmillan.

Fung, A. (2008). Citizen participation in government innovations. Dalam S. Borins (Ed.). Innovations in government: Research, recognition, and replication (h. 52-70). Washington D.C: Brookings Institution Press.

Holzhacker, R. L., Wittek, R., \& Woltjer, J. (2016). Decentralization and governance in Indonesia. Switzerland: Springer International Publishing 
AG.

Kakabadse, A., Abdulla, M. O., Abouchakra, R., \& Jawad, A. Q. (2011). Leading smart transformation: A roadmap for world class government. New York, NY: Palgrave Macmillan.

Klareskov, V., \& Nikolov, D. (2007). Eleven innovations in governance in the Middle East, North Africa, and Western Balkans: A Synopsis. Dalam Department of Economic and Social Affairs (Ed.). Innovations in governance in the Middle East, North Africa, and Western Balkans: Making governments work better in the Mediterranean Region (h. 41-52). New York: United Nations.

Lafferty, W. M. (2004). Governance for Sustainable Development: The Challenge of Adapting Form to Function. Cheltenhan: Edward Elgar.

McLaughlin, G. C., \& Kennedy, W. R. (2016). A Guide to innovation processes and solutions for government. Boca Raton, FL: CRC Press.

United Nations. (2004). Global governance and global rules for development in the post-2015. New York: United Nations Publication.

Neo, B. S., \& Chen, G. (2007). Dynamic governance: Embedding culture, capabilities and change in Singapore. Singapore: World Scientific Publishing.

Oliver, R. W. (2004). What is Transparency? New York: McGraw-Hill.

Paterson, B. L., Thorne, S. E., Canom, C., \& Jillings, C. (2001). Meta-study of qualitative health research: A practical guide to meta-analysis and meta-synthesis. Thousand Oaks, CA: SAGE Publication.

Pierre, J. (1995). Bureaucracy in the modem state: Introduction to comparative public administration. Cheltenham: Edward Elgar Publishing Limited.

Polanyi, M. (2005). Personal knowledge: Towards a post-critical philosophy. Oxford: Taylor \& Francis e-Library.

Stiglitz, J. E. (1999). On liberty, the right to know, and public discourse: The role of transparency in public life. Dalam M. Gibney (Ed.). Globalizing Rights: The Oxford Amnesty Lectures 1999 (h. 115-156). Oxford: Oxford University Press.

\section{Jurnal}

Bannister, F., \& Connolly, R. (2011). The trouble with transparency: A critical review of openness in e-government. Policy \& Internet, 3(1), 1-30. doi:10.2202/1944-2866.1076

Baybeck, B., Berry, W. D., \& Siegel, D. A. (2011). A strategic theory of policy diffusion via intergovernmental competition. The Journal of Politics, 73(1), 232-247. doi:10.1017/ S0022381610000988

Blasio, E. D., \& Selva, D. (2016). Why choose open government? motivations for the adoption of open government policies in four european countries. Policy \& Internet, 8(3), 224-247. doi:10.1002/poi3.118

Caiden, G. E. (1991). What really is public maladministration? Public Administration Review, 51(6), 486-493. Diperoleh tanggal 23 Agustus 2017, dari http://www.jstor.org/ stable/976599

Caporaso, J. A. (1978). Dependence, dependency, and power in the global system: A structural and behavioral analysis. International Organization, 32(1), 13-43. Diperoleh tanggal 23 Agustus 2017, dari http://www.jstor.org/stable/2706193

Damanpour, F. (1991). Organizational innovation: a meta-analysis of effects of determinants and moderators. The Academy of Management Journal, 34(3), 555-590. Diperoleh tanggal 11 Juli 2017, dari http://www.jstor.org/stable/256406.

Ferreira, G. (2008). Good governance and the failed state. The Comparative and International Law Journal of Southern Africa, 41(3), 428-448. Diperoleh tanggal 11 Juli 2017, dari http://www. jstor.org/stable/23253194

Firdaus. (2016). Sound governance in case of mamminasata metropolitan development area in South Sulawesi Province. Jurnal Kebijakan dan Administrasi Publik, 20(1), 1-22.

Gasco, M. (2015). Special issue on open government: an introduction. Social Science Computer Review, 33(5), 535-539. doi:10.1177/0894439314560676

Gilardi, F. (2016). Four ways we can improve policy diffusionresearch.StatePolitics\& PolicyQuarterly, 16(1), 8-21. doi:10.1177/1532440015608761

Gulbrandsen, L. H. (2014). Dynamic governance interactions: Evolutionary effects of state responses to non-state certification programs. Regulation \& Governance, 8(0), 74-92. doi:10.1111/rego.12005

Halkier, B., Katz-Gerro, T., \& Martens, L. (2011). Applying Practice Theory to the Study of Consumption: Theoretical and Methodological 
Considerations. Journal of Consumer Culture, 11(1), 3-13. doi:10.1177/1469540510391765

Herbig, P., \& Dunphy, S. (1998). Culture and innovation. Cross Cultural Management: An International Journal, 5(4), 13-21. doi:10.1108/13527609810796844

Holidin, D., \& Handini, R. S. (2014). Sound governance analysis in the innovation of traditional market revitalization and street vendors management. Bisnis \& Birokrasi, Jurnal Ilmu Administrasi dan Organisasi, 21(1), 17-26.

Kettl, D. F. (2000). The Transformation of governance: Globalization, devolution, and the role of government. Public Administration Review, 60(6), 488-497. doi:10.1111/0033-3352.00112

Kim, S., Kim, H. J., \& Lee, H. (2009). An institutional analysis of an e-government system for anticorruption: The Case of Open. Government Information Quarterly, 26(1), 42-50. doi:10.1016/j.giq.2008.09.002

Lange, P., Driessen, P. P., Sauer, A., Bornemann, B., \& Burger, P. (2013). Governing Towards Sustainability-Conceptualizing Modes of Governance. Journal of Environmental Policy \& Planning, 15(3), 403-425. doi:10.1080/152390 8X.2013.769414

Michels, A., \& Graaf, L. D. (2010). Examining citizen participation: Local participatory policy making and democracy. Local Government Studies, 36(4), 477-491. doi:10.1080/03003930.2010.494101

Namkoong, Y. (1999). Dependency theory: Concepts, classifications, and criticisms. International Area Studies Review, 2(1), 121150. doi:10.1177/223386599900200106

Nonaka, I., \& Krogh, G. v. (2009). Tacit knowledge and knowledge conversion: Controversy and advancement in organizational knowledge creation theory. Organization Science, 20(3), 635-652. doi:10.1287/orsc.1080.0412

Rajan, A. (2017). Institutional dynamics of governance reform in india (1991-2016). Indian Journal of Public Administration, 63(1), 41-62. doi:10.1177/0019556116689765

Ridla, M. R., \& Kusuma, B. M. (2016). Analisis Sound Governance Sebagai Upaya Meningkatkan Daya Saing Perguruan Tinggi Islam. Jurnal Media Dakwah, 2(2), 213-229.

Shkabatur, J. (2013). Transparency with (out) accountability: Open government in the united states. Yale Law \& Policy Review, 31(1), 1-66.
Diperoleh tanggal 15 Juli 2017, dari http:// digitalcommons.law.yale.edu/ylpr/vol31/iss1/4

Tholen, B. (2015). Citizen participation and bureaucratization: The participatory turn seen through a weberian lens. International Review of Administrative Sciences, 0(0), 1-19. doi:10.1177/0020852314548152

Volden, C., Ting, M. M., \& Carpenter, D. P. (2008). A formal model of learning and policy diffusion. The American Political Science Review, 102(3), 319-332. Diperoleh tanggal 15 Juli 2017, dari http://www.jstor.org/stable/27644523

Vries, H. d., Bekkers, V., \& Tummers, L. (2015). Innovation in the public sector: A systematics review and future research agenda. Public Administration, 94(1), 146-166. doi:10.1111/ padm.12209

Wirtz, B. W., \& Birkmeyer, S. (2015). Open government: Origin, development, and conceptual perspective. International Journal of Public Administration, 00(0), 1-16. doi:10.1080/ 01900692.2014.942735

Wirtz, B. W., Weyerer, J. C., \& Rosch, M. (2017). Citizen and open government: An empirical analysis of antecedents of open government data. International Journal of Public Administration, OO(0), 1-14. doi:10.1080/01900692.2016.12636 59

Xueliana, L., \& Lu, Y. (2016). the implications of state governance for effective global governance. Social Sciences in China, 37(4), 175-185. doi:10.1 080/02529203.2016.1241504

Yang, T.-M., Lo, J., \& Shiang, J. (2015). To open or not to open? Determinants of open government data. Journal of Information Science, 00(0), 1-17. doi:10.1177/0165551515586715

Zhao, S. (1991). "Metatheory, metamethod, meta-data analysis: What, why, and how?". Sociological Perspectives, 34(3), 377-390. doi:10.2307/1389517

Zuiderwijk, A., \& Janssen, M. (2014). The negative effects of open government data-investigating the dark side of open data. Paper dipresentasikan di Proceedings of the 15th Annual International Conference on Digital Government Research. Aguascalientes, Mexico: ACM New York, NY. doi:10.1145/2612733.2612761

\section{Disertasi}

Okechukwu, B. O. (2012). Ethical leadership and good governance in nigerian local governments. 
Dissertation Submitted of Degree of Doctor of Philosophy, Walden University, Minnesota USA.

Zimmerman, B. (2014). Transparency, sanctioning capacity, and corruption displacement: Multimethod evidence from local government in Malawi. A dissertation submitted in Doctor of Philosophy, University of California, San Diego.

\section{Sumber Digital}

World Bank. (2017, February 23). Worldwide governance indicators 2015. Diperoleh tanggal 12 Juli 2017, dari http://info.worldbank.org/ governance/wgi/\#reports

Transparency International. (2017, February 23). Corruption Perseption Index. Diperoleh tanggal 12 Juli 2017, dari ttps://www.transparency. org/news/feature/corruption_perceptions index_2016\#table

Obama, B. (2009, January 21). Transparency and Open Government: Memorandum for the Heads of Executive Departments and Agencies. Diperoleh tanggal 27 Juli 2017, dari http:// obamawhitehouse.archives.gov/the-pressoffice/transparency-and-open-government

Kemenpan RB. (2015). Hasil Evaluasi Pelaksanaan Reformasi Birokrasi, Akuntabilitas dan Zona Integritas. Diperoleh tanggal 10 Agustus 2017, dari http://evalrbkunwas.menpan.go.id/index. php/site/kabupaten

Tolbert, P. S. (2010, May 04). Robert Michels and the Iron Law of Oligarchy. Diperoleh tanggal 15 Agustus 2017, dari http://digitalcommons.ilr. cornell.edu/articles/397/

\section{Laporan}

Ombudsman. (2016). Laporan Tahunan 2015. Jakarta: Ombudsman Republik Indonesia.

\section{Peraturan Perundang-Undangan}

Undang-Undang Republik Indonesia Nomor 14 Tahun 2008 tentang Keterbukaan Informasi Publik.

Undang-Undang Republik Indonesia Nomor 23 Tahun 2014 tentang Pemerintahan Daerah.

Peraturan Pemerintah Republik Indonesia Nomor 11 Tahun 2017 tentang Manajemen Pegawai Negeri Sipil 